\title{
En jente i tidlig skolealder uten effekt av opioider ved generell anestesi
}

NOE Å LAERE AV

\section{THOMAS CHR. RISOM OLSEN}

E-post: thomas.christian.r.olsen@sykehuset-innlandet.no Anestesiavdelingen

Sykehuset Innlandet - Elverum-Hamar

Thomas Chr. Risom Olsen er spesialist i anestesiologi og assisterende avdelingsoverlege.

Forfatter har fylt ut ICMJE-skjemaet og oppgir ingen interessekonflikter.

\section{ANDERS R. RASMUSSEN}

Anestesiavdelingen

Sykehuset Innlandet - Elverum-Hamar

Anders R. Rasmussen er lege i spesialisering i anestesiologi.

Forfatter har fylt ut ICMJE-skjemaet og oppgir ingen interessekonflikter.

\section{MARIANNE K. KRINGEN}

Senter for psykofarmakologi

Diakonhjemmet Sykehus

og

Institutt for naturvitenskapelige helsefag

OsloMet-storbyuniversitetet

Marianne K. Kringen er MSc, ph.d., enhetsleder for farmakogenetiske analyser, og førsteamanuensis. Forfatter har fylt ut ICMJE-skjemaet og oppgir ingen interessekonflikter.

\section{ESPEN MOLDEN}

Senter for psykofarmakologi

Diakonhjemmet Sykehus

og

Farmasøytisk institutt

Universitetet i Oslo

Espen Molden er professor og enhetsleder for forskning.

Forfatter har fylt ut ICMJE-skjemaet og oppgir ingen interessekonflikter.

Vi beskriver her en jente som møtte til en rutineoperasjon for utstående ører. Selv om ingenting i pasientens sykehistorie skulle tilsi et uvanlig forløp av narkosen, viste det seg at barnet ikke hadde effekt av opioider.

En tidligere frisk jente i tidlig skolealder møtte til en planlagt operasjon for utstående ører. Ved anestesiologisk previsitt var det ikke noe spesielt å bemerke: Hun hadde ingen kjente allergier, hadde aldri hatt narkose tidligere, var frisk, brukte ingen faste medisiner og veide $21 \mathrm{~kg}$. Hun ble klassifisert som ASA I (frisk pasient, antatt minimal risiko ved anestesi basert på definerte kriterier (1)). Det ble planlagt total intravenøs anestesi med intubasjon, uten 
bruk av muskelrelaksantia og med lokal infiltrasjonsanestesi i operasjonsområdet på begge sider. Hun fikk peroral premedikasjon med paracetamol 6oo mg og midazolam $8 \mathrm{mg}$.

Når pasienter skal opereres for utstående ører på begge sider, er intubasjonsnarkose standard prosedyre hos oss. Hodestillingen endres underveis og man har begrenset tilgang til luftveiene uten å måtte avbryte operasjonen. Inngrepet er velegnet for lokalinfiltrasjonsanestesi, og det er av den grunn oftest ikke behov for langtidsvirkende opioider postoperativt.

Moren fulgte pasienten inn til operasjon. Det ble lagt veneflon og koblet til forhåndsprogrammerte pumper med remifentanil (kortvirkende opioid) og propofol (intravenøst anestetikum). Jenta hadde puls på 9o slag/min og $\mathrm{O}_{2}$-metning på $100 \% \mathrm{da}$ anestesien ble innledet. Remifentanilinfusjon ble startet på $0,3 \mu \mathrm{\mu g} / \mathrm{kg} / \mathrm{min}$. På grunn av uro/engstelse ble propofolinfusjonen startet nesten samtidig med en forhåndsprogrammert bolus på $4 \mathrm{mg} / \mathrm{kg}$ og deretter initial vedlikeholdsdose på $12 \mathrm{mg} / \mathrm{kg} / \mathrm{t}$. Hun sovnet raskt, og mor ble fulgt ut av operasjonsrommet. Pasienten fikk en kortvarig apné, men begynte raskt å puste spontant igjen. Hun pustet med en frekvens på 20-26 innåndinger/min og tidevolum på 120-140 ml (nærmest normalt for alderen hos en våken, rolig pasient). Remifentanilinfusjonen ble økt til opptil $1 \mu \mathrm{g} / \mathrm{kg} / \mathrm{min}$, en uventet høy dose. Det ble foretatt kontroll av veneflon, infusjonspumpe og koblinger for å utelukke paravenøs infusjon, frakobling eller feilprogrammering. Etter å ha fått knapt $4 \mu \mathrm{g} / \mathrm{kg}$ remifentanil var pasienten fortsatt uten forventede tegn på opioideffekt, og en annen anestesilege (overlege) ble kalt inn på operasjonsstuen.

Det er velkjent at det er store interindividuelle variasjoner i opioidrespons, men en dose på $4 \mu \mathrm{g} / \mathrm{kg}$ remifentanil i løpet av 7-8 minutter er $2-4$ ganger det som gir apné hos de aller fleste opioidnaive pasienter. Sammen med propofol $4 \mathrm{mg} / \mathrm{kg}$ er dette en dose som undertrykker beskyttende reflekser i svelget i en slik grad at de fleste vil kunne intuberes.

Da overlegen ankom operasjonsstuen, var pasienten sovende, men selvpustende og med normalt store pupiller. Hjertefrekvensen var $93 \mathrm{slag} / \mathrm{min}$ og blodtrykket $100 / 60 \mathrm{~mm} \mathrm{Hg}$. Det ble foretatt en ny sjekk av de vanligste feilkildene til mangelfull effekt, og en ny sprøyte med remifentanil ble rekvirert i tilfelle det skulle være noe galt med innholdet i forrige sprøyte. I mellomtiden ble det gitt raskt repeterte doser med et annet opioid, fentanyl, opptil $100 \mu \mathrm{g}$, dvs. $4,8 \mu \mathrm{g} / \mathrm{kg}$.

Remifentanil kommer i hetteglass med tørrstoff som må løses opp. Det har skjedd at man har koblet til sprøyter uten aktivt medikament (kun $\mathrm{NaCl}$ ). Derfor ble det blandet en helt ny sprøyte fra et nytt hetteglass. Opioiders relative potens varierer i litteraturen. Fentanyl er ofte oppgitt som 8o-100 ganger sterkere enn morfin per administrert dose, dvs. at $100 \mu \mathrm{g}$ fentanyl tilsvarer 8-10 mg morfin intravenøst.

Fentanyl hadde heller ingen effekt. Remifentanilsprøyten ble så byttet med en ny. Pasienten pustet fortsatt jevnt med rundt 20 innåndinger/min og med uendret tidevolum, selv med en totaldose av remifentanil på $8 \mu \mathrm{g} / \mathrm{kg}(170 \mu \mathrm{g})$ i løpet av 15-20 minutter. Det var på forhånd tilberedt en morfinsprøyte ( $2 \mathrm{mg}$ ) for eventuelt behov postoperativt. Dette ble også gitt, uten at det ga noen effekt. Man endret derfor til kombinert anestesi med gass. Sevofluran (inhalasjonsanestetikum) ble tilført, og propofolinfusjonen ble stoppet. Det var da gitt $150 \mathrm{mg}$ propofol eller litt over $7 \mathrm{mg} / \mathrm{kg}$. Det ble gitt muskelrelaksantia (cisatrakurium $3 \mathrm{mg}$ intravenøst, ca. o,15 mg/kg), og med en endetidal sevoflurankonsentrasjon på 2,9\% ble hun intubert. Pulsen økte til 140/min og blodtrykket steg fra 9o/40 mm Hg til 118/67 mm Hg. Det ble da gitt ketamin 40 mg intravenøst, og puls og blodtrykk falt igjen. Kirurgen satte lokalinfiltrasjon med bupivakain 2,5 $\mathrm{mg} / \mathrm{ml}$ med adrenalin. Narkosen ble videre opprettholdt med sevofluran og ketamin. Inngrepet ble gjennomført på i overkant av to timer. Det ble totalt gitt $100 \mathrm{mg}$ ketamin intravenøst. Deksametason 0,3 $\mathrm{mg} / \mathrm{kg}$ intravenøst ble også gitt som adjuvant smertebehandling og kvalmeprofylakse. Hun fikk NSAIDpreparatet ketorolak $10 \mathrm{mg}$ intravenøst før oppvåkning. Det postoperative forløpet var ukomplisert med paracetamol og ibuprofen som tilstrekkelig smertelindrende behandling. 
I ettertid ble det diskutert om jentas opioidresistens kunne skyldes genetiske forhold. Ansvarlig anestesilege (forfatter T.O.) snakket med pasientens foresatte umiddelbart etter operasjonen og forklarte det avvikende forløpet. De ble informert om den praktiske løsningen for smertelindring postoperativt og for de neste dagene. Skulle pasienten bli innlagt for noe annet i mellomtiden, ble de oppfordret til å ta kontakt med vår avdeling. De foresatte var enige i at det var viktig å forsøke å finne en forklaring på dette. De hadde ikke selv noen erfaring med endret eller manglende opioidrespons, og etter å ha forhørt seg med nær familie var det ingen andre der som hadde opplevd lignende.

Etter først å ha kontaktet Oslo universitetssykehus, ble problemstillingen diskutert med forskningsleder ved Senter for psykofarmakologi, Diakonhjemmet Sykehus (forfatter E.M.), der det nylig har blitt etablert et farmakogenetisk opioidpanel. Genanalyser som inngår i dette panelet, ble imidlertid antatt å ikke kunne forklare den uttalte opioidresistensen hos vår pasient. Dette fordi vår pasient ikke hadde nedsatt eller endret, men tilsynelatende totalt fraværende opioidrespons. Etter et litteraturs $ø \mathrm{k}$ ble det identifisert en nylig publikasjon fra St. Olavs hospital, der andre varianter i $\mu$-opioidreseptorgenet (OPRM1 (NM_ooog14.4)) ble presentert (2). Det ble spesielt fattet interesse for en genfeil (rs79910351, C.541C $>\mathrm{T}$ ), som koder for inaktiv (såkalt signald ød) $\mu$-opioidreseptor på grunn av en aminosyreendring i 181-posisjon av proteinet (NP_ooogo5.3, p.Arg181Cys). Genfeilen ble funksjonelt karakterisert av Ravindranathan og medarbeidere i 2009 (3). Det ble bestilt laboratoriereagenser for analyse av denne genfeilen ved Senter for psykofarmakologi, og en blodprøve av pasienten ble tatt poliklinisk. Resultatet viste at jenta var en homozygot bærer av den aktuelle varianten.

Påvisning av homozygot Arg181Cys-genfeil forklarte det kirurgiske forløpet hos jenta, der respons på potente opioider var fraværende.

I etterkant ble begge foreldrene, etter genetisk rådgivning, tilbudt å foreta farmakogenetisk analyse av Arg181Cys-genfeilen i OPRM1-genet. Både mor og far ble påvist å være heterozygote bærere. Dette innebærer at deres barn vil ha en $25 \%$ risiko for å være homozygot for genfeilen.

\section{Diskusjon}

Jenta sov på propofol og hadde ingen observerbar effekt av de intravenøse opioidene som ble administrert. Dette var et elektivt inngrep. Man kan stille spørsmål om ikke intervensjonen burde ha blitt avbrutt, ettersom opioidrespons var helt fraværende. Erfaring tilsier imidlertid at de postoperative smertene ved det aktuelle inngrepet håndteres godt uten opioider. Det brukes rutinemessig infiltrasjon med lokalanestesimiddel med lang varighet, og med tillegg av paracetamol og NSAID-preparater er det sjelden noe smerteproblem. Skulle det oppstå problemer, var man forberedt på å beholde pasienten på overvåkningsavdeling det første døgnet. Basert på dette ble det besluttet å gå videre med operasjonen.

Det ble tidlig klart at pasienten manglet normal opioidrespons. De rene my $(\mu)$-agonistene remifentanil og fentanyl hadde ingen effekt, selv i store doser. Man mistenkte allerede underveis at det var noe galt på reseptornivå. Morfin virker også noe via kappa ( $\kappa)$ - og delta ( $\delta$ )-reseptorene, og kanskje kunne høyere doser morfin hatt effekt. Smertelindrende effekt av opioider medieres i all hovedsak via $\mu$-opioidreseptorer. Den intracellulære signaloverføringen til $\mu$-reseptoren er G-proteinkoblet. Tidligere ble $\mu$-opioidreseptorer delt i $\mu 1 \operatorname{og} \mu 2$, hvor man antok at smertelindring av opioider ble mediert via $\mu 1$-stimulering, mens $\mu 2$-stimulering medierte mange av bivirkningene. Dette har senere blitt tilbakevist. De fleste mener nå at det kun er én $\mu$-opioidreseptor, og det er anbefalt å gå helt bort fra subtypeklassifisering av opioidreseptorer $(4,5)$

Genet for $\mu$-reseptoren, OPRM1, utviser betydelig polymorfisme. Man mener at dette er noe av bakgrunnen for den store variasjonen i klinisk effekt av opioidene (6). Individuelle forskjeller i opptak, metabolisme og transport over blod-hjerne-barrieren medvirker også i 
stor grad til ulik klinisk opioidrespons mellom pasienter (7), men i dette tilfellet var det altså en genfeil i OPRM1-genet som var årsaken. Den aktuelle genfeilen ble for en tid siden beskrevet av Skorpen og medarbeidere i Trondheim (2). Den medfører en utskiftning av aminosyre nummer 181 fra arginin til cystein (2). Aminosyren er lokalisert i den intracellulære delen av reseptoren, og genfeilen gjør at signaloverføring fra ekstracellulær stimulering til intracellulær respons opphører (figur 1). Personer som er homozygote bærere av denne genfeilen, som jenta i dette tilfellet var, vil derfor ikke ha noen klinisk effekt av de mest brukte opioidene ved anestesi, som fentanyl, alfentanil og remifentanil. Tilsvarende vil heller ikke andre opioider ha effekt ved smertetilstander, med mindre de også stimulerer kappa- og deltareseptorene.

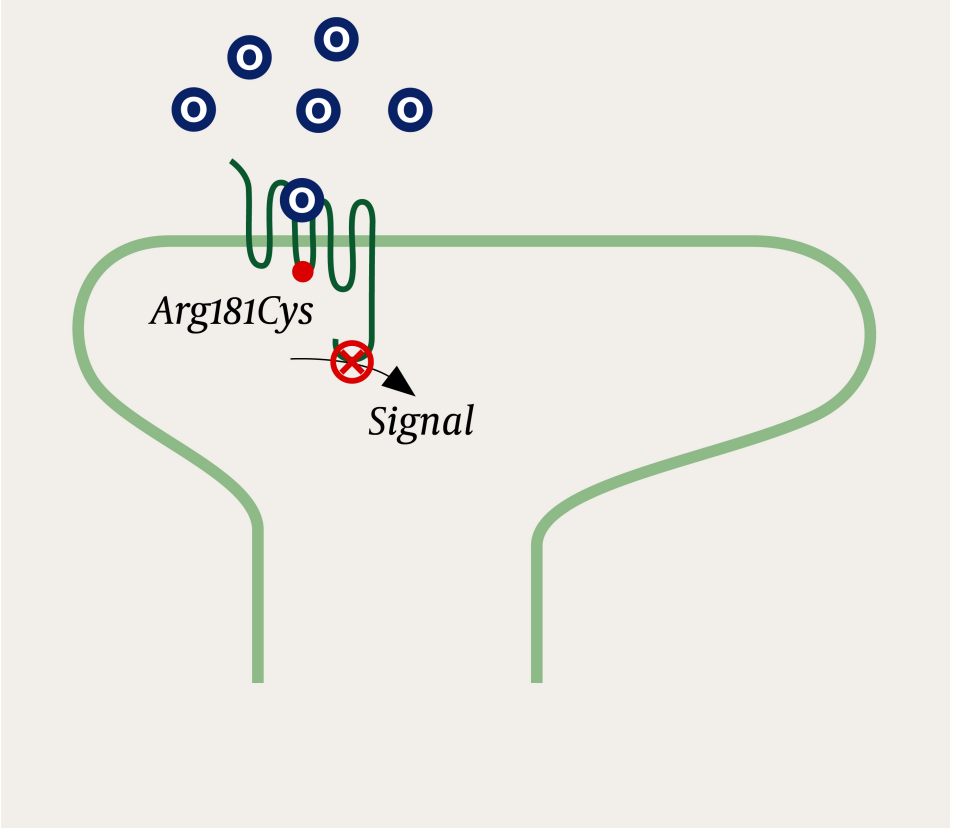

Figur 1 En opioidreseptor med Arg181Cys-genfeil. På tross av korrekt binding av opioider (O) til $\mu$ opioidreseptoren utløses ikke den intracellulcere signaloverføringen. Reseptoren er inaktiv (signaldød) (2).

Genfeilen i OPRM1-genet som var homozygot nedarvet hos jenta i denne kasuistikken, har en allelfrekvens på 0,25\% i den europeiske befolkningen (8) og ca. 1/200 (o,5\%) i den norske befolkningen, jfr. tall publisert av Skorpen og medarbeidere (2). Det betyr at frekvensen av homozygote bærere av Arg181Cys-genfeilen i OPRM1-genet er om lag 1 per 40 ooo (2). Det er derfor sjelden, men samtidig kritisk, å være helt inert mot opioider grunnet denne genfeilen. Skorpen og medarbeidere påviste også nedsatt effekt av opioider hos heterozygote bærere av Arg181Cys-genfeilen. Heterozygote bærere omfatter om lag 1 \% av befolkningen, og man vil derfor regelmessig møte disse i forbindelse med smertebehandling.

Et farmakogenetisk analysepanel for utredning av opioidrespons, som både omfatter OPRM1 (inkludert Arg181Cys-genfeilen) og relevante CYP-enzymer involvert i metabolisme av opioider, er i dag tilgjengelig som rutineanalyse ved Senter for psykofarmakologi, Diakonhjemmet Sykehus. I hvilken grad man skal teste pasienter for genfeilen i klinisk praksis, blir en diskusjon for fagmiljøet. I utgangspunktet vil det være fornuftig å vurdere farmakogenetisk analyse hos pasienter med svært uvanlig opioidrespons, da etter drøfting med spesialister i smertebehandling. Et viktig poeng i denne sammenhengen er at pasienter med langvarig bruk av opioider mot kroniske smerter, for eksempel pasienter med kreft, kan utvikle sterk opioidtoleranse uten at det har sammenheng med genfeil i OPRM1-genet. Skorpen og medarbeidere har vist at man kan forvente en $ø \mathrm{kt}$ hyppighet av Arg181Cys-genfeilen i pasientgrupper med dårlig opioidrespons. Det er derfor ønskelig med 
mer forskning som kan belyse hvor ofte farmakogenetisk variasjon forklarer mangelfull opioideffekt.

Den farmakogenetiske analysen av OPRM1 forklarte i vårt tilfelle fravær av terapeutisk respons av de nevnte opioidene. Gentestinformasjonen er også viktig for fremtiden: For jenta i denne artikkelen er det en utfordring dersom hun skulle få behov for akutt smertelindring senere i livet. Bruken av opioider er så godt innarbeidet ved akutte, moderate til sterke smerter at man må kjenne til den totale mangelen på effekt for å unngå at en slik pasient må gjennom en prøve og feile-periode for å oppnå smertelindring. En av hensiktene med den nye kjernejournalen er at denne type kritisk informasjon skal være tilgjengelig uansett hvilket norsk sykehus pasienten blir innlagt på. Dette krever imidlertid at leger manuelt legger inn opplysninger i systemet. Så langt er det ingen funksjonalitet som kobler informasjon fra kjernejournal (f.eks. genotype) med legemiddelforskrivning, slik at automatiske varsler blir generert som beslutningsgrunnlag for legen.

Pasienter som er homozygote for Arg181Cys-genfeilen i OPRM1-genet vil ha behov for tilrettelagt smertebehandling. Før eventuell kirurgi bør operatør og anestesilege legge en felles strategi for perioperativ håndtering og postoperativ smertelindring. Infiltrasjonsanestesi og perifere eller sentrale blokader vil være nyttig der det er mulig. Man bør ha en plan for håndtering av gjennombruddssmerter og eventuell svikt i en blokade. Utover basisanalgesi med paracetamol og/eller NSAID-preparater kan adjuvante midler som kortikosteroider og klonidin være aktuelle. For sterkere smerter vil ketamin i kombinasjon med et benzodiazepin eller små doser propofol være naturlig. På sykehus vil bruken av intravenøs ketamin i praksis ofte være begrenset til spesialavdelinger. Ved akutte tilstander med det som normalt vil være opioidkrevende smerter, er det trolig fornuftig at disse pasientene initialt får en overvåkningsplass med tett oppfølging av anestesilege eller andre med spesialkompetanse på smertebehandling.

\section{LITTERATUR:}

1. American Society of Anesthesiologists. ASA Physical Status Classification System. https://www.asahq.org/resources/clinical-information/asa-physical-status-classification-system (1.1.2019).

2. Skorpen F, von Hofacker S, Bjørngaard M et al. The rare Arg181Cys mutation in the $\mu$ opioid receptor can abolish opioid responses. Acta Anaesthesiol Scand 2016; 60: 1084-91. [PubMed][CrossRef]

3. Ravindranathan A, Joslyn G, Robertson M et al. Functional characterization of human variants of the mu-opioid receptor gene. Proc Natl Acad Sci U S A 2009; 106: 10811-6. [PubMed][CrossRef]

4. Dietis N, Rowbotham DJ, Lambert DG. Opioid receptor subtypes: fact or artifact? Br J Anaesth 2011; 107: 8-18. [PubMed][CrossRef]

5. Cox BM, Christie MJ, Devi L et al. Challenges for opioid receptor nomenclature: IUPHAR Review 9. Br J Pharmacol 2015; 172:317-23. [PubMed][CrossRef]

6. Knapman A, Connor M. Cellular signalling of non-synonymous single-nucleotide polymorphisms of the human $\mu$-opioid receptor (OPRM1). Br J Pharmacol 2015; 172:349-63. [PubMed][CrossRef]

7. Solhaug V, Molden E. Individual variability in clinical effect and tolerability of opioid analgesics Importance of drug interactions and pharmacogenetics. Scand J Pain 2017; 17: 193-200. [PubMed][CrossRef]

8. 2019. ExAC Database. http://exac.broadinstitute.org/ (1.1.2019).

Publisert: 31. mars 2019. Tidsskr Nor Legeforen. DOI: 10.4045/tidsskr.18.0561

Mottatt 30.6.2018, første revisjon innsendt 8.1.2019, godkjent 28.1.2019.

(C) Tidsskrift for Den norske legeforening 2020. Lastet ned fra tidsskriftet.no 